\title{
Activity-guided isolation and identification of the major antioxidant and anticancer compounds from a commercial Pelargonium sidoides tincture
}

\author{
ASP Pereira ${ }^{1}$, MJ Bester ${ }^{2}$, Soundy $\mathrm{P}^{3}$ and $\mathrm{Z}$ Apostolides ${ }^{1}$ \\ $\square$ Zeno Apostolides \\ zeno.apostolides@up.ac.za \\ Andreia Pereira \\ aspdpereira@gmail.com \\ Megan Bester \\ megan.bester@up.ac.za \\ Puffy Soundy \\ $\underline{\text { soundyp@tut.ac.za }}$

\footnotetext{
${ }^{1}$ Department of Biochemistry, Faculty of Natural and Agricultural Sciences, University of Pretoria, Pretoria 0002, South Africa. Telephone: +27-12-420-2486, Fax: +27-12-362-5302

${ }^{2}$ Department of Anatomy, Faculty of Health Sciences, University of Pretoria, Pretoria, South Africa.

${ }^{3}$ Department of Crop Sciences, Faculty of Science, Tshwane University of Technology, Pretoria, South Africa.
}

\begin{abstract}
Extracts prepared from the roots of Pelargonium sidoides (DC) are commercially available for the treatment of respiratory related conditions. Recently, a commercial radix mother tincture of this plant was shown to have both antioxidant and anticancer effects especially related to the $\mathrm{G}_{0} / \mathrm{G}_{1}$ block in the Jurkat E6.1 cell line (unpublished results). Fractions were prepared by semi-preparative HPLC, and their antioxidant and anticancer activities were determined. The more hydrophilic fractions isolated namely F6-F12 were all found to have strong reducing capacities and were able to scavenge peroxyl radicals. In the human lung cell line, NCI-H460, significant cellular antioxidant effects were observed. Anticancer activity was evaluated in the NCI-pre-screen panel (NCI-H460, MCF-7 and SF-268) and the Jurkat E6.1 cell line. Fractions F7, F9 and F12 were found to inhibit the cell growth of these four
\end{abstract}


cell-lines $(\mathrm{p}<0.05)$, especially the Jurkat E6.1 cell line with the sulforhodamine B assay. Mass spectrometry analysis revealed that these active fractions contained several polyphenolic compounds such as gallic acid, trihydroxycoumarin, dihydroxycoumarin sulfates, proanthocyanidins and phenolic glycosides. A phenolic acid glycoside sulfate not previously shown in Pelargonium sidoides extracts was also isolated. In conclusion, the antioxidant and/or anticancer activity of the Pelargonium sidoides tincture may be attributed to the presence of these polyphenolics.

Keywords - Pelargonium sidoides; activity guided fractionation; polyphenolic; coumarin; anticancer; antioxidant.

\section{Abbreviations}

AAPH: (2,2'-(2-amidinopropane) dihydrochloride). C: (catechin). DCFH-DA: (2', 7'dichlorodihydrofluorescein diacetate). DPPH: (1,1-diphenyl-2-picrylhyrazyl). EGC: (epigallocatechin). FC: (Folin-Ciocalteu). FBS: (fetal bovine serum). GA: (gallic acid). GAE: (gallic acid equivalents). GC: (gallocatechin). GI: (growth inhibition). HPLC: (highperformance liquid chromatography). LC-MS/MS: (liquid chromatography-tandem mass spectrometry). LMF: (leaf movement factor). NCI: (National Cancer Institute). ORAC: (oxygen radical absorbance capacity). PBS: (phosphate buffered saline). PLMF: (periodic leaf movement factor). PST: (Pelargonium sidoides tincture). ROS: (reactive oxygen species). RP: (reducing power). SEM: (standard error of the mean). SRB: (sulforhodamine B). SRSA: (superoxide radical scavenging assay). TX: (Trolox). TE: (Trolox equivalents). VC: (vitamin C).

\section{Introduction}

Pelargonium sidoides is a traditional medicinal plant of South Africa and Lesotho that has been widely evaluated for its use in the treatment of upper respiratory tract infections (Matthys et al., 2003, 2007; Chuchalin et al., 2005; Lizogub et al., 2007). The beneficial effects of PS can be attributed to its antiviral, antibacterial and immunomodulatory activity (Kayser and Kolodziej, 1997; Kayser et al., 2001; Kolodziej et al., 2003; Koch et al., 2006; Lewu et al., 2006; Mativandlela et al., 2006; Conrad et al., 2007; Nöldner and Schötz, 2007; Schnitzler et al., 2008: Michaelis et al., 2011). Extracts are prepared from the mature red roots of this plant. Such extracts are known to contain polyphenolic compounds such as gallic acid (GA), di- and tri-hydroxy and methoxycoumarins, coumarin sulfates, flavonoids and 
proanthocyanidins (Kolodziej, 2007). The coumarins umckalin and 6,8-dihydroxy-5,7dimethoxycoumarin as well as GA and its methyl ester are responsible for the observed antibacterial activity of plant extracts (Kayser and Kolodziej, 1997). The observed immunomodulatory activity is due to the presence of GA and its methyl ester as well as the proanthocyanidins (Kolodziej and Kiderlen, 2007; Nöldner and Schötz, 2007).

Recently, we have comprehensively evaluated the anticancer and antioxidant activity of a commercial radix mother tincture of Pelargonium sidoides (PST) (unpublished data). In this study, the tincture was shown to reduce compounds, protect cells from reactive oxygen species (ROS) as well as scavenge superoxide, nitric oxide and peroxyl radicals. Strong anticancer activity was also observed with the Jurkat E6.1 Human leukemic $\mathrm{T}$ cell lymphoblast cell line with a $\mathrm{GI}_{50}$ of $6.2 \mu \mathrm{g}$ extract $/ \mathrm{mL}$. Treatment of this cell line with the PST resulted in a $\mathrm{G}_{0} / \mathrm{G}_{1}$ phase block of the cell cycle and apoptosis. In other studies, polyphenolics like GA and proanthocyanidins have been shown to be strong antioxidants that have anticancer effects such as apoptosis induction and cell cycle phase block with in vitro human cancer cells (Arteel and Sies, 1999; Cos et al., 2002; Mansouri et al., 2005; Zhou et al., 2006; Madlener et al., 2007; Nandakumar et al., 2008; Spranger et al., 2008; Ji et al., 2009; Kaur et al., 2009; Ho et al., 2010; Di Majo et al., 2011). These same bioactive compounds may be responsible for the observed antioxidant and anticancer activity of this extract, but this needs confirmation. This study has thus been undertaken to fractionate this commercial PST, measure the antioxidant and anticancer activity in each fraction and identify the major components of the fractions with strong activities.

\section{Materials and methods}

\subsection{Chemicals}

The PST prepared according to the German Homeopathic Pharmacopoeia HAB 4a was purchased from Parceval Pharmaceuticals (Pty) Ltd., (Wellington, South Africa). This is a specialized procedure involving the extraction of 10 parts of dried root material with 100 parts of alcohol. Positive controls GA, trolox (TX) and vitamin (VC) for antioxidant assays were obtained from Sigma-Aldrich Company (Atlasville, South Africa). All other reagents for the antioxidant and anticancer assays were obtained either from Sigma-Aldrich Company (Atlasville, South Africa) or Merck (Johannesburg, South Africa). 


\subsection{Cell cultures}

The NCI-H460 human lung large cell carcinoma, SF-268 human gliomablastoma and the MCF-7 human breast adenocoarcinoma cell-lines were obtained from the National Cancer Institute (Frederick, Maryland, USA). The Jurkat E6.1 Human leukemic T cell lymphoblast cell line was obtained from the European Collection of Cell Cultures supplied by SigmaAldrich Company (Atlasville, South Africa). Cell-lines were maintained in RPMI 1640 from Sigma-Aldrich Company (Atlasville, South Africa) supplemented with 10\% fetal bovine serum and Penicillin/Streptomycin/Fungizone formulation Highveld Biological (Lyndhurst, South Africa) and maintained at $37^{\circ} \mathrm{C}, 5 \% \mathrm{CO}_{2}$.

\subsection{Fractionation of the PST}

The PST was fractionated with a Waters XBridge C18 semi-preparative column, 19 x 100 $\mathrm{mm}$ with $5 \mu \mathrm{m}$ particle size. The column was fitted with a Waters XBridge C18 guard column, 19 x $10 \mathrm{~mm}$ with $5 \mu \mathrm{m}$ particle size. Fractionation was performed with a Waters 600 controller and pump connected to a Waters 717 autosampler and Waters In-Line DegasserAF. Chromatograms were captured with a Waters 996 Photodiode Array detector and visualized with the Empower 3 software. Fractionation was performed with a Waters Fraction Collector III. All Waters products were supplied by Microsep (Pty) Ltd (Johannesburg, South Africa). Solvent A was water with 5\% methanol (v/v) and $0.1 \%$ formic acid (v/v). Solvent B was water with $70 \%$ methanol (v/v) and $0.1 \%$ formic acid (v/v). Two $\mathrm{ml}$ of the PS tincture was injected for each run. The separation was achieved on a linear gradient from $0 \%-100 \%$ B over 50 minutes followed by 10 minutes at $100 \%$ solvent B and returned to starting conditions over 12 minutes on a linear gradient. The flow rate was $10 \mathrm{~mL} / \mathrm{min}$ and fractions were collected every minute for 34 minutes into $10 \mathrm{~mL}$ plastic tubes. The column eluent was monitored at $330 \mathrm{~nm}$, and fractionation was performed at room temperature. A total of $20 \times 2$ $\mathrm{mL}$ injections were fractionated. The fractions collected from each run were pooled and stored at $4^{\circ} \mathrm{C}$ until freeze drying. For the freeze drying, the fractions were placed in $250 \mathrm{~mL}$ conical flasks and snap frozen in liquid nitrogen. The fractions were freeze dried on a FreeZone 2.5 Liter Freeze Dry System from Vacutec (Johannesburg, South Africa) coupled to a Labconco Rotary Vane Vacuum pump from Vacutec (Johannesburg, South Africa). A glass cold trap from NTP Radioisotopes (Pty) Ltd. (Pelindaba, South Africa) was fitted between the freeze drier and the vacuum pump and filled with liquid nitrogen to trap any methanol before the pump. The freeze dried fractions were stored at $-20^{\circ} \mathrm{C}$ until needed. For 
bio-assays, fractions F2-19 were prepared as $1 \mathrm{mg} / \mathrm{ml}$ stock solutions in $\operatorname{dddH}_{2} \mathrm{O}$, while fractions F20-29 were prepared as $1 \mathrm{mg} / \mathrm{mL}$ stock solutions with $30 \%$ methanol (v/v). Fractions were filtered through a $0.2 \mu \mathrm{m}$ Acrodisc PSF syringe filter with GHP membrane, aliquoted and stored at $-20^{\circ} \mathrm{C}$.

\subsection{Antioxidant assays}

\subsubsection{Folin-Ciocalteu assay}

The Folin-Ciocalteu assay was based on the assay of Biglari et al. (2008) with some modifications. Briefly, a Folin-Ciocalteu working solution was prepared from the stock solution by diluting the stock $10 \mathrm{x}$ with $\mathrm{dddH}_{2} \mathrm{O}$. One hundred $\mu \mathrm{L}$ of Folin-Ciocalteu working solution was added to $20 \mu \mathrm{L}$ of sample in a microtiter plate and mixed on a microtiter plate shaker. Each sample was evaluated at a concentration of $100 \mu \mathrm{g} / \mathrm{mL}$. Thereafter, $80 \mu \mathrm{L}$ of a $7.5 \%(\mathrm{w} / \mathrm{v})$ sodium carbonate solution prepared in $\mathrm{dddH}_{2} \mathrm{O}$ was added, mixed and incubated at room temperature for 60 minutes. The absorbency was measured at $760 \mathrm{~nm}$ with a Multiscan Ascent plate reader from AEC Amersham (Kelvin, South Africa). Water was used as a blank, and a standard curve was constructed with a $1 \mathrm{mg} / \mathrm{mL}$ GA solution prepared in $\mathrm{dddH}_{2} \mathrm{O}$, linear concentration range from 7.8 to $125 \mu \mathrm{g} / \mathrm{mL}$. Samples were expressed as $\mathrm{mg}$ gallic acid equivalents (GAE)/g of sample.

\subsubsection{The DPPH radical scavenging assay}

The DPPH radical scavenging assay was adapted from Kumaran and Karunakaran (2007). Briefly, $200 \mu \mathrm{L}$ of a $0.04 \mathrm{mM}$ DPPH solution prepared in methanol was incubated with 20 $\mu \mathrm{L}$ of different concentrations of the samples in the dark at room temperature for 60 minutes. The disappearance of the purple DPPH to a pale yellow color was measured at $492 \mathrm{~nm}$ with a Multiscan Ascent plate reader from AEC Amersham (Kelvin, South Africa). Water was used as the blank. The $\mathrm{IC}_{50}$ value was determined with the median-effect equation of $\mathrm{T}-\mathrm{C}$ Chou and calculated with the Calcusyn programme for Windows software (version 2.0, 2004) (Chou, 1991).

\subsubsection{The ORAC assay}

The ORAC assay was adapted from Serem and Bester (2012). Each sample was evaluated in the ORAC assay at a concentration of $15 \mu \mathrm{g} / \mathrm{mL}$. A $200 \mathrm{nM}$ fluorescein stock solution was prepared in $\mathrm{dddH}_{2} \mathrm{O}$ and stored at $-20^{\circ} \mathrm{C}$. The fluorescein working solution was prepared by 


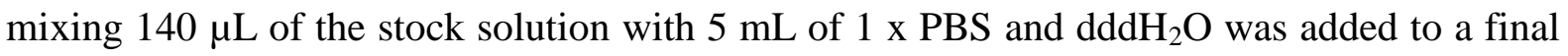
volume of $50 \mathrm{~mL}$. The reaction solution contained $16 \mathrm{~mL}$ of the fluorescein working solution and $4 \mathrm{~mL}$ of a $295 \mathrm{mM}$ AAPH solution prepared in $\mathrm{dddH}_{2} \mathrm{O}$. An aliquot of ten $\mu \mathrm{L}$ of each sample was added to $200 \mu \mathrm{L}$ of the reaction solution. The fluorescence of the reaction was monitored for 4 hours at 480/520 nm (excitation/emission wavelengths) on the FLUOstar Optima fluorescent plate reader from BMG Labtech GmbH (Allmendgruen, Germany). The area under the curve (AUC) was determined with the Microcal Origin software version 6.0. The AUC is used to quantify the ORAC of each sample (Ou et al., 2001). TX was used to generate a standard curve (concentration range $1.56 \mu \mathrm{g} / \mathrm{mL}$ to $100 \mu \mathrm{g} / \mathrm{mL}$ ), and results are expressed as mg TE/g of sample.

\subsubsection{The DCFH-DA intracellular ROS assay}

The DCFH-DA intracellular ROS assay was adapted from Serem and Bester (2012). The NCI H460 human lung cancer cell line was used to evaluate the ability of each sample to inhibit ROS generation by AAPH in vitro. Briefly, 7500 cells/well in RPMI-1640 medium containing $10 \%$ FBS were seeded in 96-well plates and incubated overnight at $37^{\circ} \mathrm{C}, 5 \% \mathrm{CO}_{2}$. Forty $\mu \mathrm{L}$ of a $20 \mu \mathrm{M}$ DCFH-DA solution in 1x PBS was added, and the cells were incubated for 60 minutes. The medium was then removed, and cells were washed with 1x PBS. Forty $\mu \mathrm{L}$ of $30 \mu \mathrm{M}$ AAPH solution in $\mathrm{dddH}_{2} \mathrm{O}$ and $40 \mu \mathrm{L}$ of different concentrations of the samples were added. The fluorescence was monitored every 2 minutes for 60 minutes at 480/520 nm (excitation/emission) on the FLUOstar Optima fluorescent plate reader from BMG Labtech $\mathrm{GmbH}$ (Allmendgruen, Germany). The slope of the measured fluorescence was determined

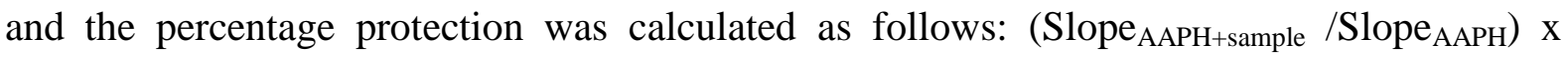
$100 \%$. The $\mathrm{IC}_{50}$ value was determined with the median-effect equation of $\mathrm{T}-\mathrm{C}$ Chou and calculated with the Calcusyn programme for Windows software (version 2.0, 2004) (Chou, 1991).

\subsection{Anti-proliferative activity}

The anti-proliferative effect of each fraction was determined by the NCI-pre-screen panel (NCI-H460, SF-268 and MCF-7) and the Jurkat cell line. Briefly, cells were plated in 96-well culture plates in $100 \mu \mathrm{L}$ of RPMI medium with $10 \% \mathrm{FBS}(\mathrm{v} / \mathrm{v})$ at the following cell densities: 7500 cells/mL for NCI-H460, 15000 cells/mL for SF-268, 10000 cells/mL for MCF-7 and 20000 cells $/ \mathrm{mL}$ for Jurkat cells. Cells were left to settle for 24 hours at $37^{\circ} \mathrm{C}$ and $5 \% \mathrm{CO}_{2}$. The NCI pre-screen panel was exposed to a concentration of $30 \mu \mathrm{g} / \mathrm{mL}$ while the Jurkat cells 
were exposed to a concentration of $5 \mu \mathrm{g} / \mathrm{mL}$. Each fraction was added in $100 \mu \mathrm{L}$ of RPMI medium with $10 \%$ FBS (v/v) and the cells were left for a further 72 hours at $37^{\circ} \mathrm{C}$ and $5 \%$ $\mathrm{CO}_{2}$. Following the 72 hour exposure period, the anticancer activity was evaluated with the SRB assay.

Briefly, cells were fixed with $50 \mu \mathrm{L}$ of a $50 \%$ cold trichloroacetic acid solution (w/v) for 60 minutes at $4^{\circ} \mathrm{C}$. Thereafter, plates were washed with water and left to dry. Plates were stained with a $0.4 \%$ SRB solution (w/v) in $1 \%$ acetic acid solution (v/v) for 10 minutes, washed with $1 \%$ acetic acid solution and left to dry. The dye was then solubilized with $200 \mu \mathrm{L}$ of a $10 \mathrm{mM}$ Tris base solution $\mathrm{pH} \mathrm{10.5}$, and the absorbance was determined at $550 \mathrm{~nm}$ with $690 \mathrm{~nm}$ as the reference with a Multiscan Ascent plate reader from AEC Amersham (Kelvin, South Africa).

The percentage GI was determined as follows: $100-\left[\left(T-T_{0}\right) /\left(C-T_{0}\right) \times 100\right]$ where $T$ is the absorbance of the cell growth in the presence of a drug concentration, $\mathrm{T}_{0}$ the initial cell growth before any drugs were added, and C is the control cell growth (Boyd and Paull, 1995).

\subsection{LC-MS/MS analysis of active fractions}

Analysis of the active PST fractions was performed on a Waters UPLC Acquity system fitted with a Waters Acquity PDA and coupled to a Waters Synapt G2 mass spectrometer (Milford, Massachusetts, USA). The fractions were analyzed with a Waters Acquity UPLC BEH C18 column, 2.1 x $100 \mathrm{~mm}$ with $1.7 \mu \mathrm{m}$ particle size coupled with a Waters Acquity UPLC BEH C18 pre-column, $2.1 \times 5 \mathrm{~mm}$ with $1.7 \mu \mathrm{m}$ particle size. The column temperature was set at $55^{\circ} \mathrm{C}$ and the solvents used were HPLC grade water (solvent A) and HPLC grade acetonitrile (solvent B). Four $\mu \mathrm{L}$ of each fraction was injected, and the flow rate was set at $0.2 \mathrm{ml} / \mathrm{min}$. The chromatographic conditions were as follows: $5 \%$ solvent $\mathrm{B}$ for first 5 minutes, $5 \%$ to 95\% solvent B over 45 minutes, 95\% solvent B was maintained for 5 minutes and returned to starting conditions of $5 \%$ solvent B over 5 minutes on a linear gradient. The mass spectrometer was operated in the negative ionization mode, and mass data was acquired from 50 to $1500 \mathrm{amu}$. Conditions were as follows: capillary voltage $2.5 \mathrm{kV}$, sampling cone voltage 15 , desolvation temperature $275^{\circ} \mathrm{C}$, desolvation gas flow $650 \mathrm{~L} / \mathrm{hr}$ and cone gas flow of 50 $\mathrm{L} / \mathrm{hr}$. A low-energy function with trap collision energy of $4 \mathrm{~V}$ and a high-energy function with trap collision energy that ramped from 15 to $60 \mathrm{~V}$ to generate $\mathrm{MS}^{\mathrm{e}}$ spectra, were used to acquire the mass data. Data was processed with Waters MassLynx V4.1 software. Compounds were tentatively identified based on their mass, fragmentation patterns and comparison with previous literature. 


\subsection{Statistical analysis}

Each experiment was conducted in triplicate and each data point represents the mean \pm the standard error of the mean (SEM). The statistical significance of each fraction's IC $_{50}$ and GI value was determined with the Tukey honestly significant difference test following analysis of variance (ANOVA). Pearson's product-moment correlation coefficients to determine the linear dependence of two assays were also calculated. Both calculations were done with JMP version 9.0.0 software. Differences between mean values were considered significant where $\mathrm{P}$ values $<0.05$

\section{Results and discussion}

\subsection{Fractionation of PST}

Fractions from the PST were collected on a C18 semi-preparative HPLC column. The fractions were collected every minute for 34 minutes since no more peaks were visible after 34 minutes (Figure 1). Umckalin was identified by comparison of the retention time and PDA spectrum with an umckalin standard. Only 28 of the 34 fractions collected had a mass of 1 mg or more after freeze drying, and thus only these were used in the antioxidant and anticancer assays (Table 1). Majority of the mass of the PST was found in fraction F3 representing $48.5 \%$ of the extract. A total of $550 \mathrm{mg}$ of the extract was injected and fractionated and after freeze drying the combined mass of all the fractions collected was 499 mg. The percentage recovery from this method was $90.73 \%$ indicating that this was an effective method to isolate active compounds from plant extracts.

\subsection{Antioxidant activity}

Oxidative stress has been implicated as the cause of several diseases, and it is also involved in the pathogenesis of some diseases. Antioxidant activity of the fractions was evaluated in a series of standard antioxidant assays that measure three different antioxidant parameters namely; 1) reducing capacity, 2) direct scavenging of peroxyl radicals 3 ) the ability to protect cells in vitro from oxidative stress, and the results are summarized in Table 1. The antioxidant capacity was compared to three well known antioxidant compounds namely GA, TX and VC that served as positive controls.

The reducing capacity of the fractions was evaluated with the FC and DPPH radical scavenging assays. The reducing capacity of a compound gives a good indication of the 


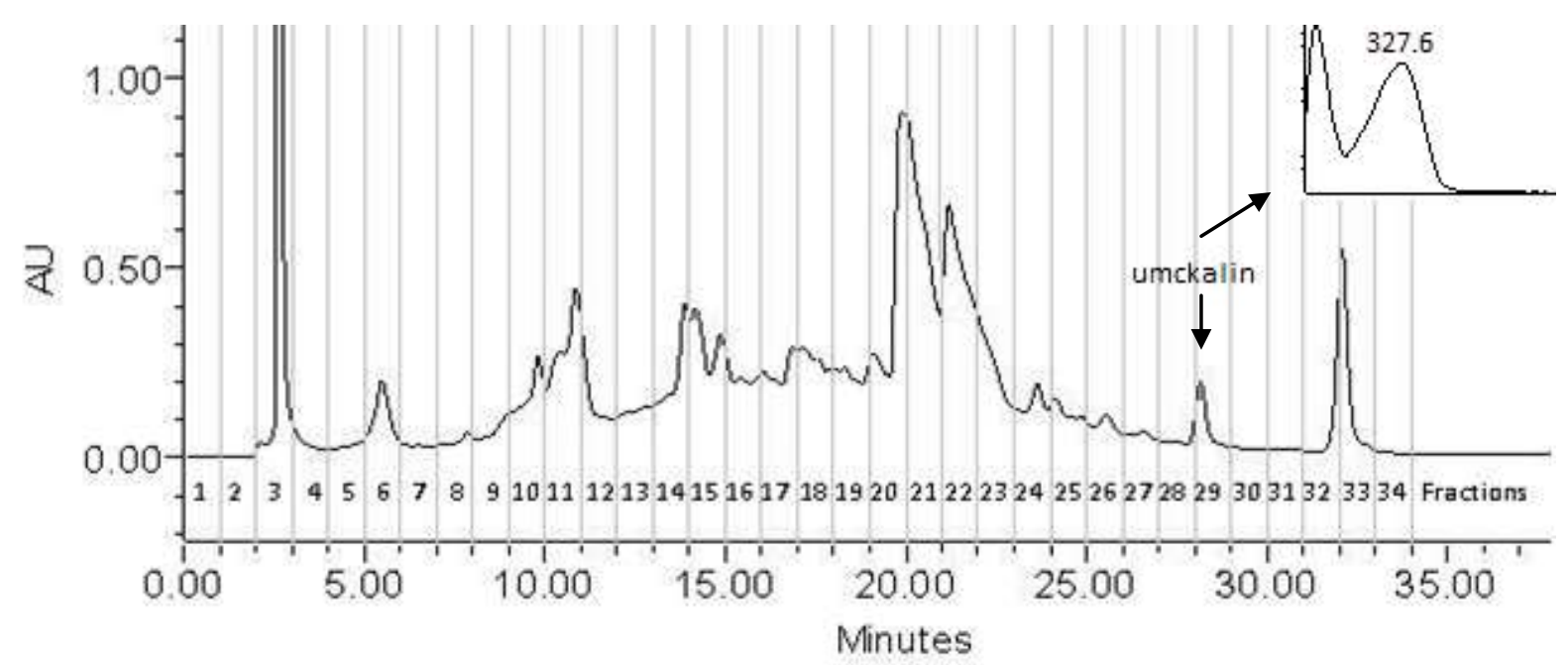

Fig 1 PDA chromatogram of the PST for fractionation Extract was fractionated on a Waters XBridge C18 semipreparative column, $19 \times 100 \mathrm{~mm}$ with $5 \mu \mathrm{m}$ particle size. Solvent A: $5 \%$ methanol, $0.1 \%$ formic acid; solvent B: $70 \%$ methanol, $0.1 \%$ formic acid. Separation was achieved over a linear gradient from $0-100 \%$ B over 50 minutes. Flow rate was $10 \mathrm{~mL} / \mathrm{min}$ and detector was set at $330 \mathrm{~nm}$. Injection volume was $2 \mathrm{~mL}$ containing 27.5 $\mathrm{mg}$ of extract. Tubes containing $10 \mathrm{~mL}$ volumes of each fraction of the PS tincture collected every minute for 34 minutes

potential antioxidant capacity of the compound (Meir et al., 1995). These two assays involve the transfer of electrons (Foti et al., 2004; Huang et al., 2005; Vukovic et al., 2010). Several of the fractions were found to have strong reducing capacity that was comparable to the three positive controls. With the FC assay, six fractions namely F8, F9, F12, F13, F15 and F28 had a significantly stronger $(\mathrm{P}<0.05)$ reducing capacity than the positive control $\mathrm{VC}$, on an equal mass basis. Another eight fractions had significantly stronger activity than positive control TX. For the DPPH assay; the majority of the fractions showed a similar reducing capacity to that of the three positive controls. Only fractions F2, F22, F25, F26 and F27 were significantly weaker than the positive controls. Taken collectively, five fractions namely F9, F10, F12, F14 and F15 were found with both assays to have the strongest reducing capacity of all the fractions evaluated.

The ability of each fraction to scavenge peroxyl radicals was also evaluated. These are biologically relevant radicals responsible for damaging lipids, proteins and DNA (Southorn and Powis, 1996). The ORAC assay involves the transfer of hydrogen atoms from the antioxidants to neutralize the peroxyl radicals generated by AAPH (Ou et al., 2001). The positive control GA, was highly efficient in neutralizing the peroxyl radicals in the ORAC 
assay with an ORAC of $2669 \mathrm{mg}$ TE/g. Only F7 was found to have an ORAC of $2722 \mathrm{mg}$

$\mathrm{TE} / \mathrm{g}$ that was similar to GA. The positive control VC, showed weak activity with an ORAC

Table 1. Summary of mass of PST fractions collected, antioxidant assays, means and standard error of the mean

\begin{tabular}{|c|c|c|c|c|c|c|}
\hline Name & $\begin{array}{l}\text { Mass } \\
(\mathrm{mg})\end{array}$ & $\begin{array}{l}\text { Percentage } \\
\text { Recovered }\end{array}$ & $\begin{array}{c}\mathrm{FC} \\
(\mathrm{mgGAE} / \mathrm{g})\end{array}$ & $\begin{array}{c}\text { DPPH IC }_{50} \\
(\mu \mathrm{g} / \mathrm{mL})\end{array}$ & $\begin{array}{c}\text { ORAC } \\
(\mathrm{mgTE} / \mathrm{g})\end{array}$ & $\begin{array}{c}\text { DCFH-DA IC }_{50} \\
(\mu \mathrm{g} / \mathrm{mL})\end{array}$ \\
\hline F2 & 21.9 & 4.0 & inactive & inactive & inactive & inactive \\
\hline F3 & 265.9 & 48.4 & $294(5.8)^{\operatorname{lm}}$ & $139(4.2)^{\mathrm{c}}$ & $888(64)^{\text {fghij }}$ & $29(0.7)^{\mathrm{c}}$ \\
\hline F4 & 4.6 & 0.8 & $408(3.5)^{1}$ & $89(1.2)^{\mathrm{de}}$ & $641(42)^{\mathrm{jkl}}$ & $12(0.1)^{\mathrm{ef}}$ \\
\hline F5 & 1.2 & 0.2 & $401(36)^{1}$ & $77(1.6)^{\mathrm{def}}$ & $1058(55)^{\text {efgh }}$ & $5.0(0.4)^{\mathrm{ijkl}}$ \\
\hline F6 & 2.9 & 0.5 & $597(56)^{\text {ghi }}$ & $44(2.2)^{\text {fghij }}$ & $1157(51)^{\mathrm{ef}}$ & $3.3(0.4)^{j \mathrm{kl}}$ \\
\hline F7 & 2.6 & 0.5 & $641(17)^{\text {efghi }}$ & $29(2.3)^{\mathrm{ij}}$ & $2722(63)^{a}$ & $2.8(0.3)^{\mathrm{kl}}$ \\
\hline F8 & 6.2 & 1.1 & $873(42)^{b c}$ & $43(2.4)^{\text {fghij }}$ & $1537(96)^{\mathrm{cd}}$ & $4.7(0.3)^{\mathrm{ijkl}}$ \\
\hline F9 & 7.9 & 1.4 & $1018(55)^{\mathrm{a}}$ & $35(2.1)^{\mathrm{ij}}$ & $1457(64)^{\mathrm{cd}}$ & $3.1(0.3)^{\mathrm{jkl}}$ \\
\hline F10 & 9.5 & 1.7 & $715(7.5)^{\text {defgh }}$ & $41(1.0)^{\text {ghij }}$ & $1588(72)^{c}$ & $5.5(0.3)^{\text {hijkl }}$ \\
\hline F11 & 10.3 & 1.9 & $606(5.3)^{\text {ghi }}$ & $49(0.9)^{\text {fghi }}$ & $1589(72)^{\mathrm{c}}$ & $4.2(0.4)^{\mathrm{ijkl}}$ \\
\hline F12 & 12.6 & 2.3 & $758(3.1)^{\text {cdef }}$ & $22(0.9)^{\mathrm{ij}}$ & $1113(38)^{\text {efg }}$ & $1.3(0.1)^{1}$ \\
\hline F13 & 13.5 & 2.5 & $807(15)^{\mathrm{cd}}$ & $43(3.6)^{\text {fghij }}$ & $803(45)^{\mathrm{hijkl}}$ & $14(0.5)^{\mathrm{e}}$ \\
\hline F14 & 15.6 & 2.8 & $630(2.7)^{\mathrm{fghi}}$ & $41(1.8)^{\mathrm{ghij}}$ & $751(48)^{\mathrm{ijkl}}$ & $4.6(0.2)^{\mathrm{ijkl}}$ \\
\hline F15 & 18.5 & 3.4 & $770(5.7)^{\text {cde }}$ & $41(2.7)^{\mathrm{hij}}$ & $1548(73)^{\mathrm{cd}}$ & $8.4(0.5)^{\mathrm{fghi}}$ \\
\hline F16 & 11.4 & 2.1 & $560(8.9)^{\mathrm{ijk}}$ & $38(1.1)^{\mathrm{ij}}$ & $1203(31)^{\mathrm{efg}}$ & $11(0.3)^{\mathrm{efg}}$ \\
\hline F17 & 14.5 & 2.9 & $632(4.4)^{\text {efghi }}$ & $48(2.1)^{\text {fghij }}$ & $574(10)^{\mathrm{kl}}$ & $7.9(0.6)^{\text {fghij }}$ \\
\hline F18 & 13.8 & 2.5 & $565(5.8)^{\mathrm{ij}}$ & $40(2.8)^{\mathrm{ij}}$ & $1074(61)^{\text {efgh }}$ & $5.1(0.2)^{\mathrm{ijkl}}$ \\
\hline F19 & 8.7 & 1.6 & $428(8.9)^{\mathrm{jkl}}$ & $56(2.3)^{\text {efghi }}$ & $683(48)^{\mathrm{jkl}}$ & $11(0.5)^{\mathrm{efg}}$ \\
\hline F20 & 13.2 & 2.4 & $387(5.1)^{1}$ & $77(0.9)^{\operatorname{defg}}$ & $703(24)^{\mathrm{jkl}}$ & $12(0.2)^{\mathrm{efg}}$ \\
\hline F21 & 11.9 & 2.2 & $243(1.9)^{\mathrm{mn}}$ & $92(1.8)^{\operatorname{defg}}$ & $817(49)^{\text {ghijkl }}$ & $10(0.9)^{\mathrm{efgh}}$ \\
\hline $\mathrm{F} 22$ & 10.5 & 1.9 & $118(2.4)^{\mathrm{n}}$ & $304(9.7)^{\mathrm{b}}$ & $774(16)^{\mathrm{hijkl}}$ & $44(1.7)^{b}$ \\
\hline F23 & 7.1 & 1.3 & $309(0.9)^{\operatorname{lm}}$ & $166(10)^{\mathrm{c}}$ & $1047(32)^{\text {efghi }}$ & $33(2.4)^{\mathrm{c}}$ \\
\hline F24 & 4.9 & 0.9 & $308(3.5)^{\mathrm{lm}}$ & $142(8.4)^{\mathrm{c}}$ & $868(17)^{\text {fghijk }}$ & $19(0.9)^{\mathrm{d}}$ \\
\hline F25 & 3.9 & 0.8 & $219(2.2)^{\mathrm{mn}}$ & $383(16)^{\mathrm{a}}$ & $683(40)^{\mathrm{jkl}}$ & $44(1.2)^{b}$ \\
\hline F26 & 2.4 & 0.4 & $138(8.7)^{\mathrm{n}}$ & $386(18)^{\mathrm{a}}$ & $688(43)^{\mathrm{jkl}}$ & $33(1.3)^{\mathrm{c}}$ \\
\hline F27 & 1.4 & 0.3 & $209(9.6)^{\mathrm{mn}}$ & $295(16)^{\mathrm{b}}$ & $750(60)^{\mathrm{ijk} l}$ & $52(2.2)^{\mathrm{a}}$ \\
\hline F28 & 1.1 & 0.2 & $734(86)^{\text {cdefg }}$ & $76(3.1)^{\text {defgh }}$ & $1993(34)^{\mathrm{b}}$ & $6.7(0.4)^{\text {ghijk }}$ \\
\hline F29 & 1.0 & 0.2 & $561(31)^{\mathrm{ij}}$ & $86(2.1)^{\mathrm{de}}$ & $1283(19)^{\mathrm{de}}$ & $19(1.7)^{\mathrm{d}}$ \\
\hline GA & n.a. & n.a. & n.a. & $14(1.1)^{\mathrm{j}}$ & $2669(130)^{\mathrm{a}}$ & $1.0(0.03)^{1}$ \\
\hline $\mathrm{TX}$ & n.a. & n.a. & $422(7.3)^{\mathrm{kl}}$ & $48(4.2)^{\mathrm{fghij}}$ & n.a. & $2.1(0.3)^{\mathrm{kl}}$ \\
\hline $\mathrm{VC}$ & n.a. & n.a. & $593(2.4)^{\mathrm{hi}}$ & $39(0.6)^{\mathrm{ij}}$ & $543(16)^{1}$ & $11(0.9)^{\mathrm{efg}}$ \\
\hline
\end{tabular}

Total injected $=20$ injections $\times 27.5 \mathrm{mg}(2 \mathrm{~mL}$ injections $)=550 \mathrm{mg}$; Total collected after freeze drying $=499 \mathrm{mg}$; Recovery $=90.7 \%$. FC: Folin-Ciocalteu assay in mg GA equivalents/g of sample; ORAC assay in mg Trolox equivalents/g of sample. Standard error of the mean in parentheses. Samples in each column, not connected by the same letter (a-n), are significantly different at $95 \%$ level of confidence. 
of only $543 \mathrm{mg}$ TE/g. More than half of the fractions, namely fractions F3, F5-F12, F15, F16, F18, F23, F24, F28 and F29, had significantly better activity than VC on an equal mass basis.

Each fraction was evaluated for its ability to protect NCI-H460 cells from ROS generated by AAPH. Cells were treated with non-fluorescent DCFH-DA that crosses the cell membrane, and in the presence of ROS is converted into a fluorescent DCF compound (Afri et al., 2004). Eleven of the fractions namely F5-12, F14, F18 and F28 had IC $_{50}$ values similar to that of GA and TX ranging from 1 to $7 \mu \mathrm{g} / \mathrm{mL}$. Fractions F4, F13, F16, F17 and F19-21 had $\mathrm{IC}_{50}$ values similar to VC.

With all antioxidant assays, a similar trend was observed. The more hydrophilic fractions isolated, particularly F7-F12, displayed the stronger antioxidant activity with all four antioxidant assays. These fractions were also observed with the FC assay to have high polyphenolic content. The presence of these polyphenols in the fractions likely explains their strong antioxidant activity. Polyphenolic compounds are natural antioxidants capable of scavenging different radicals and chelating metal ions (Rice-Evans et al., 1996; Heim et al., 2002).

\subsection{Anti-proliferative activity}

The anti-proliferative activity of the 28 isolated fractions was evaluated in vitro with the Jurkat cell line and the NCI-prescreen panel (NCI-H460, MCF-7 and SF-268 cell-lines). Compounds/plant extracts are first evaluated with this panel for anticancer activity, and only the active compounds/plant extracts are further evaluated in the NCI 60 cell line panel (Takimoto, 2003). The Jurkat cell line, a human leukaemia cell line, was included in the analysis as leukaemias are a prevalent form of childhood cancers (Ma et al., 2010). Also, coumarins (the type of compound that the PST was found to be rich in, not shown) have been suggested as potential lead candidates for the treatment of haematological malignancies (Riviero et al., 2008).

Only plant extracts that have an $\mathrm{IC}_{50}$ of $30 \mu \mathrm{g} / \mathrm{mL}$ or less are considered for further evaluation (Itharat et al., 2004; Steenkamp and Gouws, 2006). As the fractions were isolated from a crude extract, only the fractions that caused more than $75 \%$ cell GI at $30 \mu \mathrm{g} / \mathrm{mL}$ in two or more cell lines would be considered for future evaluation. Fractions were evaluated at $5 \mu \mathrm{g} / \mathrm{mL}$ in the Jurkat cell line as this cell line was found to be very sensitive to the PST 
(unpublished data). Cells were exposed to the fractions for 72 hours, and their effect on cell growth was quantified with the SRB assay (Figure 2).

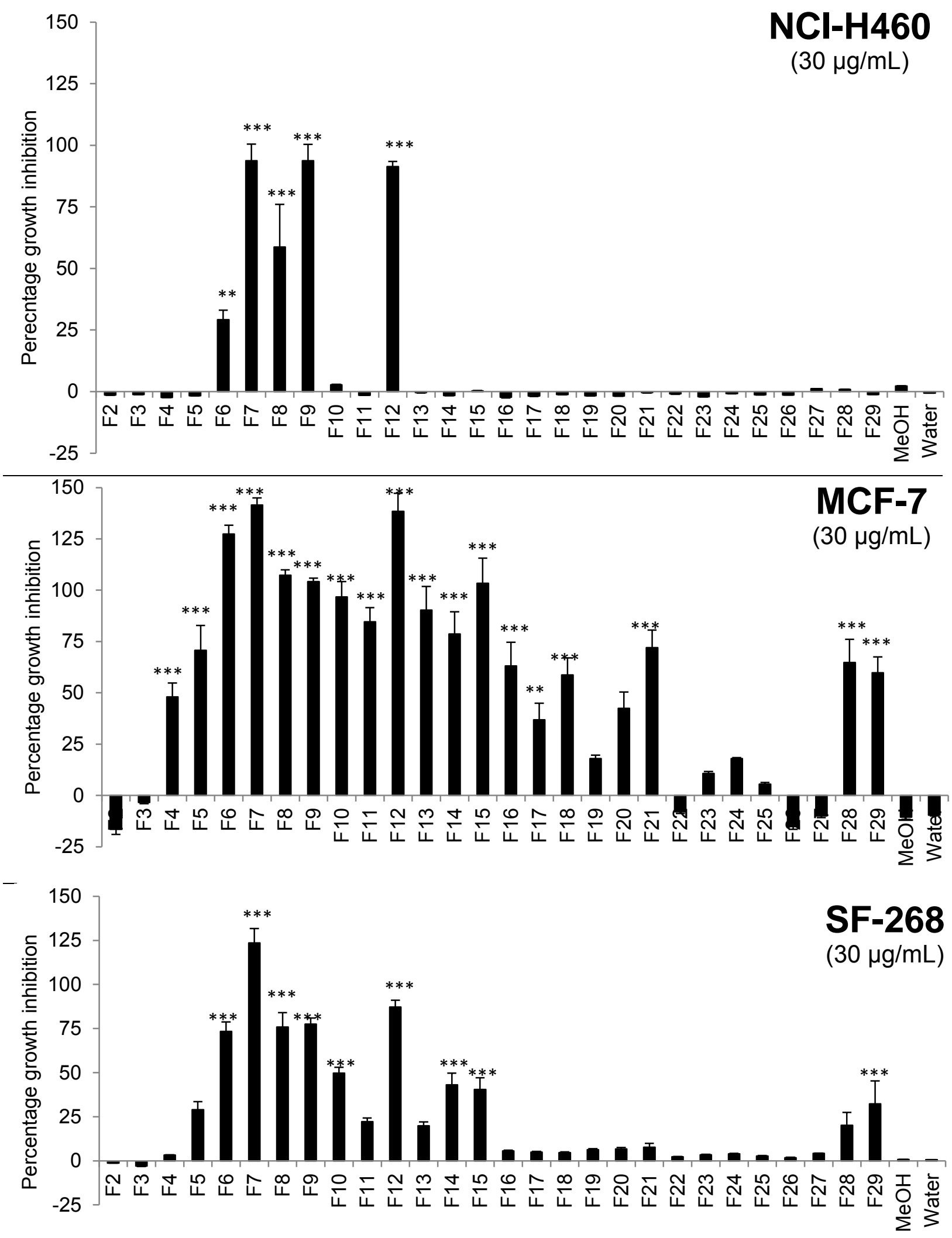




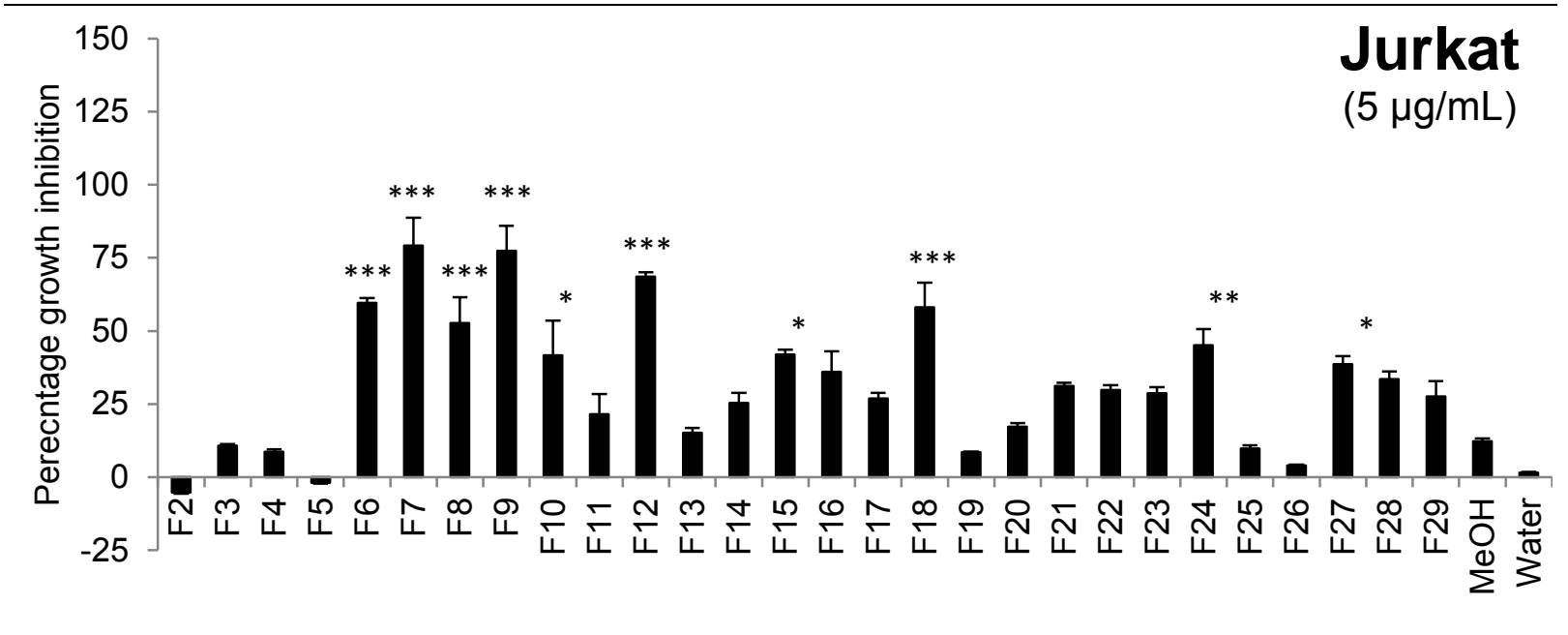

Fig 2 Percentage GI induced in NCI-H460, MCF-7, SF-268 and Jurkat cell-lines following treatment with PST fractions Cells were exposed to $30 \mu \mathrm{g} / \mathrm{mL}$ (NCI-H460, MCF-7 and SF-268) or $5 \mu \mathrm{g} / \mathrm{mL}$ (Jurkat) of each PS fraction for 72 hours and percentage GI was quantified with the SRB assay. Water and $0.9 \%$ methanol served as negative controls. Three independent experiments were conducted, and each column represents the mean with the SEM. *: significant at the $95 \%$ level of confidence; $* *$ significant at the $99 \%$ level confidence; $* * *$ significant at the $99.9 \%$ level of confidence

The percentage GI was calculated relative to the control and the initial number of cells before treatment started was taken into account. GI percentages above $100 \%$ indicated that the compounds inhibited cell growth completely, and induced cell death. The number of cells following treatment was less than the initial number of cell before treatment started. GI percentages below $0 \%$ reflected that treatment stimulated cell growth. The number of cells after treatment was higher than that of the control cell population that received no treatment.

The NCI-H460 cells were resistant to treatment with the fractions. Only four of the fractions were found to have a significant effect on GI $(\mathrm{P}<0.001)$ with fractions F7, F9 and F12 causing almost complete cell GI (more than 75\%). The MCF-7 cell line was sensitive to treatment with several fractions having a significant effect on cell growth $(\mathrm{P}<0.001)$. Fractions F6, F7, F8, F9, F12 and F15 induced cell death at this concentration. Another four fractions F10, F11, F13 and F14 caused greater than 75\% cell GI. Some of the fractions namely F2, F22, F26, F27, water control and $0.9 \%$ methanol control were observed to stimulate cell growth (negative GI), but this was not statistically significant. The SF-268 cell line like the NCI-H460 cell line was slightly more resistant to treatment with the fractions with only four fractions F6, F8, F9 and F12 causing more than 75\% cell death. Fraction F7 
did, however, as in the MCF-7 cell line, induced cell death. Treatment of the Jurkat cell line with the fractions resulted in only three of the fractions F7, F9 and F12 causing 75\% or more GI.

A similar trend was observed for anticancer activity as was seen with antioxidant activity where the more hydrophilic fractions had stronger anticancer activity than the more hydrophobic fractions in the four cell-lines. Only fractions F6, F7, F8, F9 and F12 caused more than $75 \%$ cell GI in two or more cell lines, and of these fractions, F7, F9 and F12 showed strong anticancer activity in all four cell lines. These five fractions also showed strong antioxidant activity and high polyphenolic content suggesting that the polyphenolics in these fractions may account for the observed anticancer activity of these fractions.

\subsection{Correlation of antioxidant assays}

Pearson's product-moment correlation coefficients were calculated to determine whether a linear relationship existed between any of antioxidant assays (Table 2). The inverse of the

Table 2. Pearson's product-moment correlation coefficients for antioxidant assays

\begin{tabular}{lcccc}
\hline & FC & DPPH & ORAC & DCFH-DA \\
\hline FC & 1 & & & $0.90^{* * *}$ \\
DPPH & & 1 & 1 & 1 \\
ORAC & $0.60^{* * * *}$ & & & \\
DCFH-DA & & $0.90^{* * * *}$ & & \\
$1 /$ DPPH & $0.77^{* * * *}$ & & $0.62^{* * *}$ & \\
$1 /$ DCFH-DA & $0.57^{* * *}$ & & $0.57^{* * *}$ & \\
\hline
\end{tabular}

${ }^{* * *} \mathrm{P}<0.001$.

$\mathrm{IC}_{50}$ values for the DPPH radical scavenging and DCFH-DA intracellular ROS assays were correlated with the FC and ORAC assays as it was expected that the more GA and TX equivalents a compound had, the better the reducing and scavenging ability and thus lower $\mathrm{IC}_{50}$ for the fractions. Strong correlations were found between the two reducing power assays namely FC and 1/DPPH with Pearson's coefficients above 0.75 and $\mathrm{P}<0.001$. These assays are based on a one electron transfer reaction, and thus it is expected that these assays should correlate well. Good correlations between these assays have also been found by other authors (Sultana et al., 2007; Rao et al., 2010; Rawat et al., 2011). Relatively good correlation was seen with FC and the other antioxidant assays indicating that the polyphenolic compounds present in the fractions can explain some of the observed antioxidant activity. Good 
correlation was also found between the DPPH assay and the DCFH-DA intracellular ROS assay $(0.90, \mathrm{P}<0.001)$ as well as between 1/DPPH and ORAC $(0.62, \mathrm{P}<0.001)$ indicating that compounds present in the fractions that are good reductants are also good scavengers of peroxyl radicals. This could be seen with positive controls GA and TX. Strong inverse correlations between DPPH and ORAC have also been observed by Teow et al. (2007) and Li et al. (2009).

\subsection{LC-MS/MS analysis of active fractions}

Of the 28 fractions isolated from the PST, only seven fractions namely F6- F12, were observed to have significant antioxidant as well as anti-proliferative activity. These active fractions represented only a small percentage of the mother tincture mass injected ranging from $0.05 \%$ to $2.3 \%$ for fractions F6-F12. In comparison with the antioxidant capacity of the mother tincture, these hydrophilic fractions had stronger antioxidant activity than the mother tincture (unpublished data). These fractions also displayed stronger anticancer activity than the mother tincture that displayed weak anticancer activity in the NCI-pre-screen panel with $\mathrm{GI}_{50}$ values ranging from 40 to $80 \mu \mathrm{g} / \mathrm{mL}$. These observations indicate that the type of compounds present in these fractions, are present in the mother tincture at a low concentration, and that they influence the bioactivity of the mother tincture. Also, other compounds present in the mother tincture may be having antagonistic associations with the bioactive constituents of the mother tincture, and thus higher effective concentrations of the mother tincture are needed.

These seven fractions were analyzed with LC-MS/MS in an attempt to identify the compound/s responsible for the observed antioxidant and anticancer activity. The fractions were relatively complex in nature containing three to seven different compounds. Some of the compounds could be tentatively identified based on fragmentation patterns, UV-vis spectrum and previous literature (Table 3). Pelargonium sidoides extracts have previously been shown to contain several phenolic compounds (Kolodziej, 2007) and the fractions evaluated here were also found to be rich in phenolic compounds. Fractions were found to contain several polyphenolic compounds such as GA $(169 \mathrm{~m} / \mathrm{z})$, dihydroxycoumarin sulfate $(273 \mathrm{~m} / \mathrm{z})$, trihydroxycoumarin (193 m/z), GC-GC proanthocyanidin dimer $(609 \mathrm{~m} / \mathrm{z}), \quad$ C-CG pronathocyanidin dimer $(593 \mathrm{~m} / \mathrm{z})$, GC-GC-GC proanthocyanidin trimer $(913 \mathrm{~m} / \mathrm{z})$ as well as phenolic glucoside koaburaside $(331 \mathrm{~m} / \mathrm{z})$. All the identified compounds in the fractions were also found in the mother tincture (not shown). Several of these compounds such as the 
Table 3. Major peaks of fractions F6-F12 according to mass spectra obtained in the negative ionization mode.

\begin{tabular}{|c|c|c|c|c|c|c|c|c|}
\hline Fraction & $\begin{array}{c}\mathrm{T}_{\mathrm{r}} \\
\min \end{array}$ & $\begin{array}{c}\text { Accurate mass } \\
{\left[\mathrm{M}-\mathrm{H}^{-}\right]}\end{array}$ & $\begin{array}{l}\text { Proposed } \\
\text { formula }\end{array}$ & $\begin{array}{l}\text { Error } \\
(\mathrm{ppm})\end{array}$ & MS/MS fragment ions & $\begin{array}{l}\lambda_{\max } \\
(\mathrm{nm})\end{array}$ & Proposed compound & Reference \\
\hline \multirow[t]{6}{*}{6} & 2.46 & 169.0130 & $\mathrm{C}_{7} \mathrm{H}_{5} \mathrm{O}_{5}$ & -4.1 & 125 & 271 & GA & Kim et al., 2009 \\
\hline & 3.37 & 272.9705 & $\mathrm{C}_{9} \mathrm{H}_{5} \mathrm{O}_{8} \mathrm{~S}$ & 0 & 193 & 323 & Dihydroxycoumarin sulfate & Gödecke et al., 2005 \\
\hline & 4.46 & 331.1039 & $\mathrm{C}_{14} \mathrm{H}_{19} \mathrm{O}_{9}$ & 3 & 169,139 & 273 & Koaburaside & Chung et al., 1997 \\
\hline & 5.77 & 365.0177 & $\mathrm{C}_{12} \mathrm{H}_{13} \mathrm{O}_{11} \mathrm{~S}$ & 3.8 & $347,211,153$ & 339 & Phenolic glycoside sulfate & New \\
\hline & 6.05 & 272.9708 & $\mathrm{C}_{9} \mathrm{H}_{5} \mathrm{O}_{8} \mathrm{~S}$ & 2.6 & 193 & 258,321 & Dihydroxycoumarin sulfate & Gödecke et al., 2005 \\
\hline & 6.74 & 193.0147 & $\mathrm{C}_{9} \mathrm{H}_{6} \mathrm{O}_{5}$ & -1 & $177,149,121$ & 332 & Trihydroxycoumarin & Kayser and Kolodziej, 1995 \\
\hline \multirow[t]{6}{*}{7} & 2.46 & 169.0135 & $\mathrm{C}_{7} \mathrm{H}_{5} \mathrm{O}_{5}$ & -1.2 & 125 & 271 & GA & Kim et al., 2009 \\
\hline & 3.68 & 344.0409 & $\mathrm{C}_{10} \mathrm{H}_{11} \mathrm{~N}_{5} \mathrm{O}_{7} \mathrm{P}$ & -3.2 & $153,150,133$ & 252 & LMF 2 & Schildnecht 1983 \\
\hline & 3.87 & 328.0460 & $\mathrm{C}_{10} \mathrm{H}_{11} \mathrm{~N}_{5} \mathrm{O}_{6} \mathrm{P}$ & 2.7 & 134 & 257 & LMF 3 & Schildnecht 1983 \\
\hline & 4.22 & 411.0231 & $\mathrm{C}_{13} \mathrm{H}_{15} \mathrm{O}_{13} \mathrm{~S}$ & 1.7 & $241,169,125$ & 255 & PLMF 1 & Schildnecht 1983 \\
\hline & 4.46 & 331.1039 & $\mathrm{C}_{14} \mathrm{H}_{19} \mathrm{O}_{9}$ & 3 & 169,139 & 273 & Koaburaside & Chung et al., 1997 \\
\hline & 5.73 & 365.0177 & $\mathrm{C}_{12} \mathrm{H}_{13} \mathrm{O}_{11} \mathrm{~S}$ & -0.8 & $347,211,153$ & 314 & Phenolic glycoside sulfate & New \\
\hline \multirow[t]{5}{*}{8} & 4.45 & 331.1032 & $\mathrm{C}_{14} \mathrm{H}_{19} \mathrm{O}_{9}$ & 0.9 & 169,139 & 273 & Koaburaside & Chung et al., 1997 \\
\hline & 4.70 & 609.1243 & $\mathrm{C}_{30} \mathrm{H}_{25} \mathrm{O}_{14}$ & -0.2 & $441,423,305,177,125$ & 273 & GC-GC dimer & Callemien and Collin, 2008 \\
\hline & 4.87 & 611.1393 & $\mathrm{C}_{30} \mathrm{H}_{27} \mathrm{O}_{14}$ & -1.3 & 305,249 & 273 & GC-GC dimer & Callemien and Collin, 2008 \\
\hline & 5.46 & 609.1261 & $\mathrm{C}_{30} \mathrm{H}_{25} \mathrm{O}_{14}$ & 2.8 & $441,423,305,177,125$ & 273 & GC-GC dimer & Callemien and Collin, 2008 \\
\hline & 7.39 & 611.1401 & $\mathrm{C}_{30} \mathrm{H}_{27} \mathrm{O}_{14}$ & 0 & $305,179,125$ & 273 & GC-GC dimer & Callemien and Collin, 2008 \\
\hline \multirow[t]{4}{*}{9} & 4.86 & 611.1402 & $\mathrm{C}_{30} \mathrm{H}_{27} \mathrm{O}_{14}$ & 0.2 & $305,179,125$ & 273 & GC-GC dimer & Callemien and Collin, 2008 \\
\hline & 5.42 & 609.1243 & $\mathrm{C}_{30} \mathrm{H}_{25} \mathrm{O}_{14}$ & -0.2 & $441,423,305,177,125$ & 273 & GC-GC dimer & Callemien and Collin, 2008 \\
\hline & 5.67 & 272.9708 & $\mathrm{C}_{9} \mathrm{H}_{5} \mathrm{O}_{8} \mathrm{~S}$ & 1.5 & 193 & 340 & Dihydroxycoumarin sulfate & Gödecke et al., 2005 \\
\hline & 7.40 & 611.1391 & $\mathrm{C}_{30} \mathrm{H}_{27} \mathrm{O}_{14}$ & -1.6 & $305,177,125$ & 273 & GC-GC dimer & Callemien and Collin, 2008 \\
\hline \multirow[t]{3}{*}{10} & 4.88 & 611.1403 & $\mathrm{C}_{30} \mathrm{H}_{27} \mathrm{O}_{14}$ & 0.3 & $305,179,125$ & 273 & GC-GC dimer & Callemien and Collin, 2008 \\
\hline & 5.72 & 272.9700 & $\mathrm{C}_{9} \mathrm{H}_{5} \mathrm{O}_{8} \mathrm{~S}$ & -1.8 & 193 & 340 & Dihydroxycoumarin sulfate & Gödecke et al., 2005 \\
\hline & 6.74 & 193.0147 & $\mathrm{C}_{9} \mathrm{H}_{6} \mathrm{O}_{5}$ & 1.6 & $175,149,121$ & 333 & Trihydroxycoumarin & Kayser and Kolodziej, 1995 \\
\hline \multirow[t]{2}{*}{11} & 5.71 & 365.0181 & $\mathrm{C}_{12} \mathrm{H}_{13} \mathrm{O}_{11} \mathrm{~S}$ & 0.5 & $347,211,153$ & 337 & Phenolic glycoside sulfate & New \\
\hline & 5.92 & 272.9709 & $\mathrm{C}_{9} \mathrm{H}_{5} \mathrm{O}_{8} \mathrm{~S}$ & 1.5 & 193 & 258,321 & Dihydroxycoumarin sulfate & Gödecke et al., 2005 \\
\hline
\end{tabular}




\begin{tabular}{|c|c|c|c|c|c|c|c|c|}
\hline & 6.74 & 193.0147 & $\mathrm{C}_{9} \mathrm{H}_{6} \mathrm{O}_{5}$ & -1.0 & $175,149,125$ & 331 & Trihydroxycoumarin & Kayser and Kolodziej, 1995 \\
\hline \multirow[t]{7}{*}{12} & 4.69 & 609.1266 & $\mathrm{C}_{30} \mathrm{H}_{25} \mathrm{O}_{14}$ & 3.6 & $423,305,177,125$ & 273 & GC-GC dimer & Callemien and Collin, 2008 \\
\hline & 6.03 & 272.9703 & $\mathrm{C}_{9} \mathrm{H}_{5} \mathrm{O}_{8} \mathrm{~S}$ & -0.7 & 193 & 258,321 & Dihydroxycoumarin sulfate & Gödecke et al., 2005 \\
\hline & 6.62 & 593.1258 & $\mathrm{C}_{30} \mathrm{H}_{25} \mathrm{O}_{13}$ & -1.7 & $425,407,305,289,177,137$ & 273 & C-GC dimer & Callemien and Collin, 2008 \\
\hline & 7.00 & 272.9695 & $\mathrm{C}_{9} \mathrm{H}_{5} \mathrm{O}_{8} \mathrm{~S}$ & -3.7 & 193 & 280 & Dihydroxycoumarin sulfate & Gödecke et al., 2005 \\
\hline & 7.74 & 913.1767 & $\mathrm{C}_{45} \mathrm{H}_{37} \mathrm{O}_{21}$ & -6.6 & $609,423,305,177,125$ & 273 & GC-GC-GC trimer & Callemien and Collin, 2008 \\
\hline & 8.10 & 911.1680 & $\mathrm{C}_{45} \mathrm{H}_{35} \mathrm{O}_{21}$ & 1.0 & $608,423,305,177,125$ & 273 & GC-GC-GC trimer & Callemien and Collin, 2008 \\
\hline & 8.70 & 913.1702 & $\mathrm{C}_{45} \mathrm{H}_{35} \mathrm{O}_{21}$ & -13.7 & $608,423,305,303,177,125$ & 273 & GC-GC-GC trimer & Callemien and Collin, 2008 \\
\hline
\end{tabular}


turgorins, koaburaside and new phenolic acid glycoside sulfate represented only minor peaks in the crude extract suggesting low concentrations of these compounds. The chemical structures and fragmentation patterns of the compounds can be seen in Figure 3. Proanthocyanidin dimers and trimers were the main compound type of fractions F9, F8 and F12. The coumarins were found in F6, F9, F10, F11 and F12 for dihydroxycoumarin sulfates and F6, F10 and F11 for trihydroxycoumarin. The PST was also shown to contain several structural isomers of dihydroxycoumarin sulfate and trihydroxycoumarin (unpublished data).
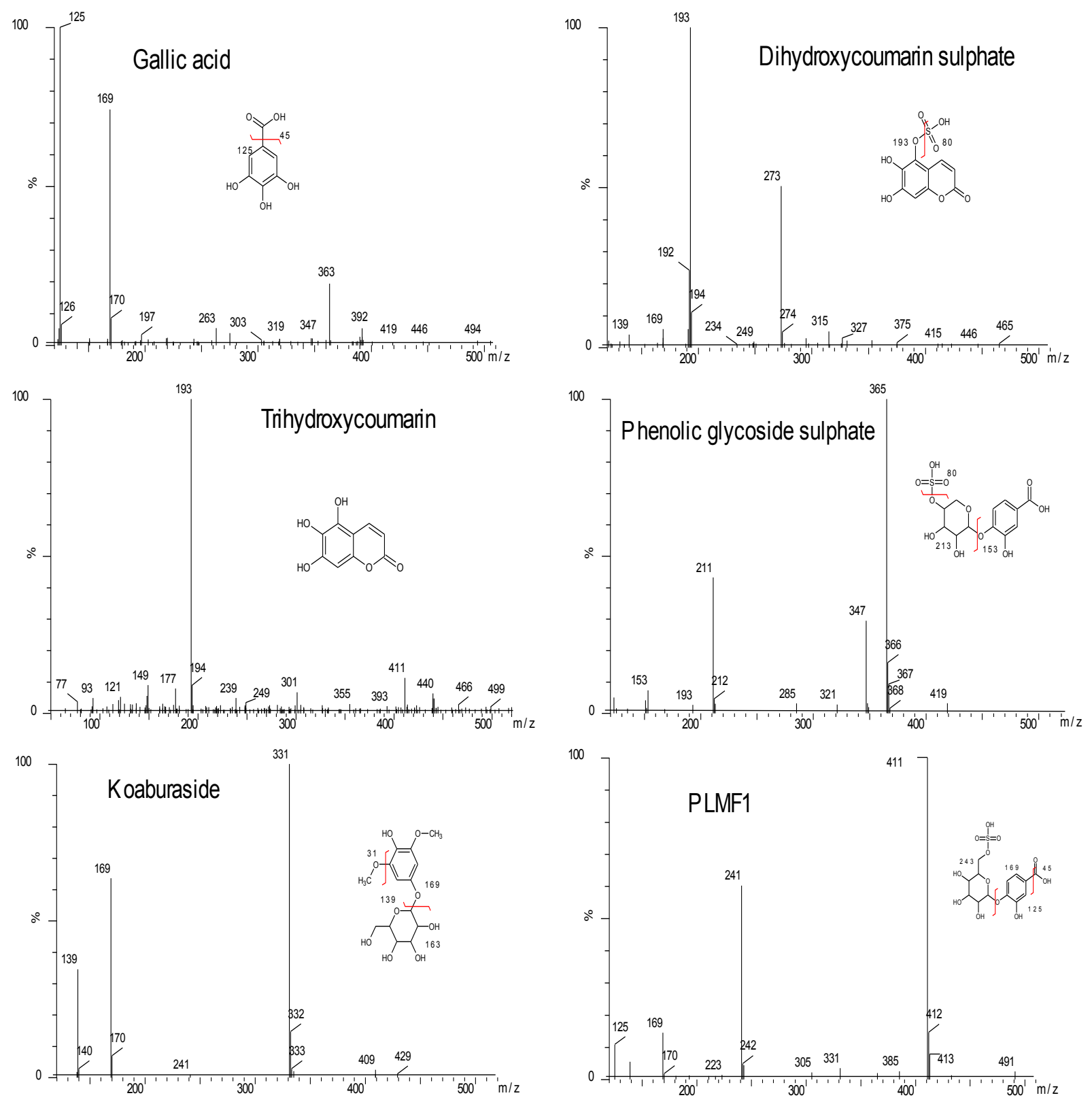

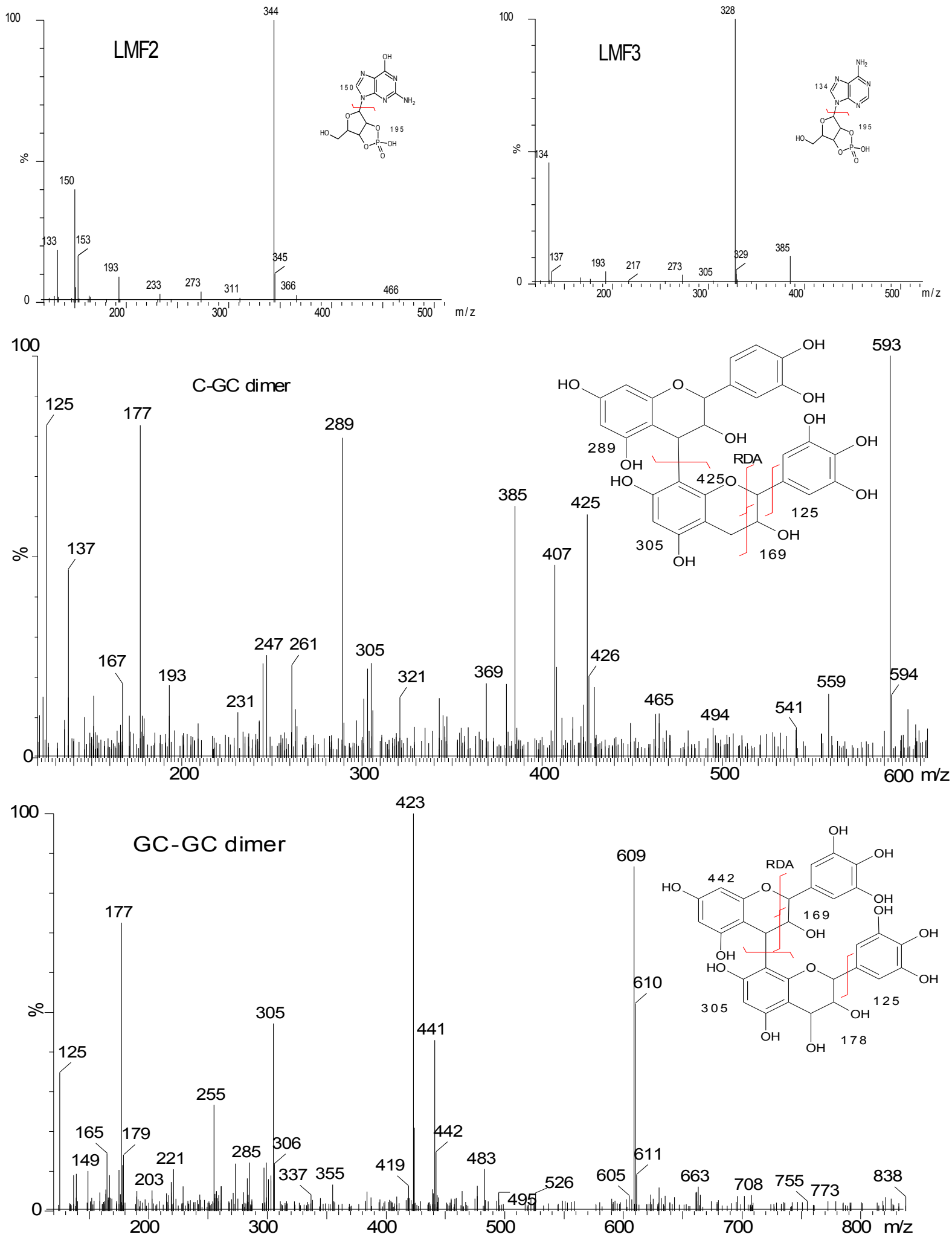


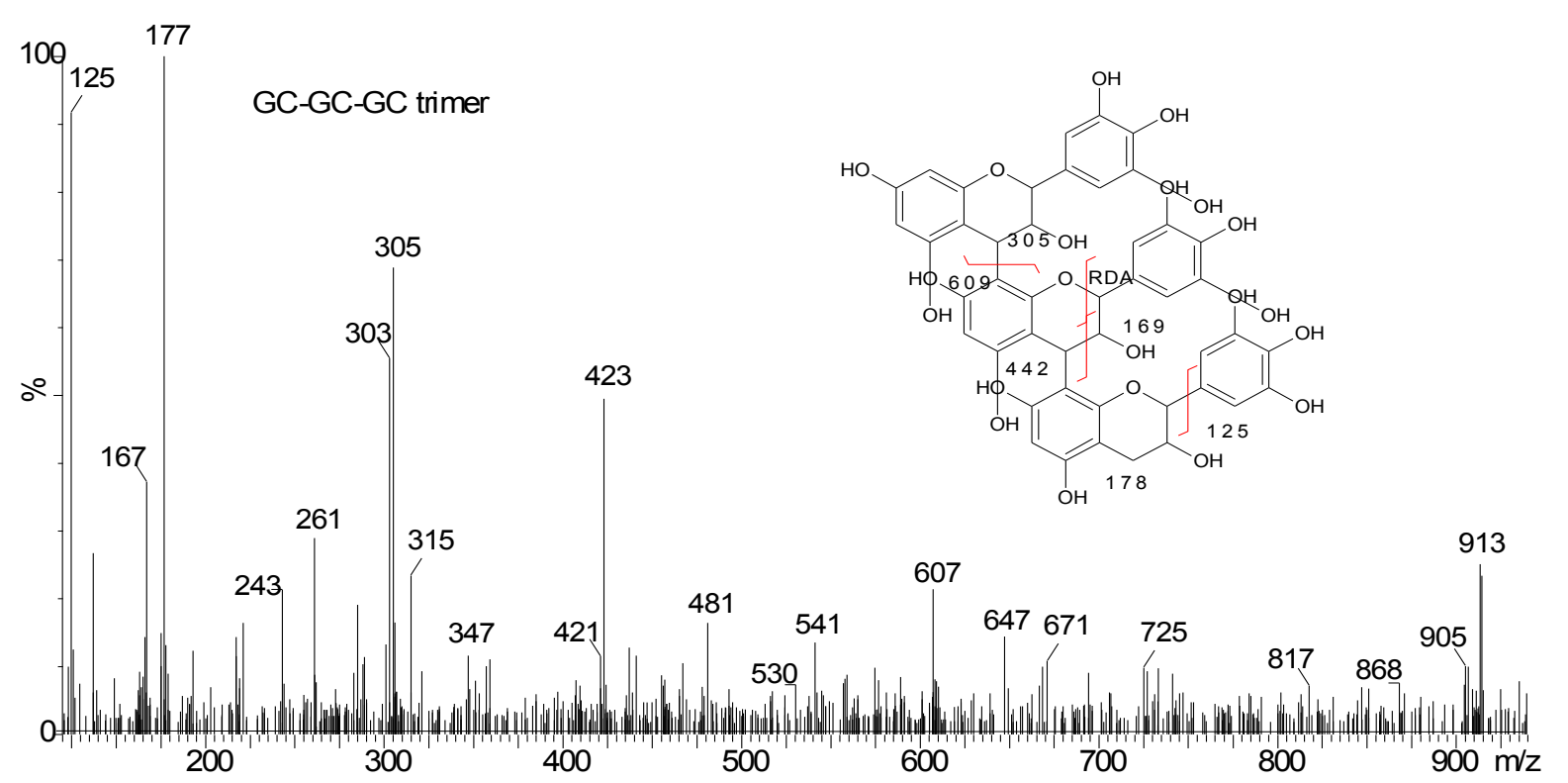

Fig 3 Molecular structures and fragmentation patterns of compounds identified in PST fractions F6-F12 RDA; retro-Diels-Alder fission

Only fraction F7 contained the three turgorins namely LMF $2(344 \mathrm{~m} / \mathrm{z})$, LMF $3(328 \mathrm{~m} / \mathrm{z})$ and PLMF $1(411 \mathrm{~m} / \mathrm{z})$. These are movement hormones responsible for the nastic movements of plants in response to light, dark and touch and are predominantly found within the leaf tissue of plants (Schildknecht, 1984). The compound with $365 \mathrm{~m} / \mathrm{z}$ at a retention time of 5.7 minutes was tentatively identified as a new phenolic acid glycoside sulfate similar to PLMF 1. Mass fragments $211 \mathrm{~m} / \mathrm{z}$ represent a sulfated xylopyranose sugar, and hydroxybenzoic acid protocatechuic acid may represent mass fragment $153 \mathrm{~m} / \mathrm{z}$ (Pérez-Magariño et al., 1999). This compound has not previously been shown in Pelargonium sidoides extracts. This compound as well as GA, dihydroxycoumarin sulfate and trihydroxycoumarin could be found in more than one fraction. The semi-preparative column was slightly overloaded to collect more of each fraction with each injection, and this could be a result of peak broadening. Also, as these active fractions were collected in series, it was expected that some compounds would be present in adjoining fractions. This, however, cannot be applied to the presence of the new $365 \mathrm{~m} / \mathrm{z}$ compound (F7 and F11) and trihydroxycoumarin (F6 and F10) that appeared in fractions collected 4 minutes apart. The trihydroxycoumarin appearing in the fraction F6 may represent a mass fragment of dihydroxycoumarin sulfate that has lost its sulfate group. Two structural isomers of dihydroxycoumarin were found in this fraction. Similarly, the appearance of new $365 \mathrm{~m} / \mathrm{z}$ compound in F7 and F11 may be explained by the loss of a mass fragment or existence of this compound as a dimer. Additional masses of $419 \mathrm{~m} / \mathrm{z}$ (loss of 54 $\mathrm{m} / \mathrm{z}$ ) and $731 \mathrm{~m} / \mathrm{z}$ (dimer) were observed in the mass fragmentation pattern of this compound. 
The compounds identified in the bioactive fractions are expected to contribute to the observed antioxidant activity of the PST. Strong antioxidant activity has been shown for GA and proanthocyanidins by other authors (Bagchi et al., 2000; Cos et al., 2002; Spranger et al., 2008; Sroka and Cisowski, 2003). Some antioxidant activity is expected for the phenolic acid glycoside sulfate $365 \mathrm{~m} / \mathrm{z}$ and PLMF 1 due to the presence of hydroxybenzoic acid groups. The antioxidant activity, however, is expected to be weaker than the aglycones due to the presence of the electron withdrawing glycoside sulfate groups. Similarly, the phenolic glucoside koaburaside should also contribute some antioxidant activity. Koaburaside was shown by He et al. (2011) to scavenge DPPH radicals. The substitution of koaburaside is similar to that of syringic acid (hydroxybenzoic acid) and synaptic acid (hydroxycinnamic acid). These two phenolic acids have been shown to be scavengers of peroxyl, peroxynitrite, DPPH, ABTS ${ }^{+}$, hydroxyl and superoxide radicals (Heijnen et al., 2001; Zhou et al., 2006). The hydroxylated coumarin compounds are expected to be strong antioxidants as well. A study by Bailly et al. (2004) showed that a 3,6,7-trihydroxycoumarin was a good scavenger of superoxide, hydroxyl and peroxynitrite radicals. The dihydroxycoumarin sulfates will be expected to be weaker antioxidants than the trihydroxycoumarins due to the presence of the electron withdrawing sulfate group.

Similarly, several of the identified compounds are also expected to contribute to the antiproliferative activity. The PST was observed to arrest the cell cycle and induce apoptosis in Jurkat leukemia cells (unpublished data). GA and proanthocyanidins have been shown to arrest the cell cycle, induce apoptosis, inhibit angiogenesis and tumor invasion in vitro (Ji et al., 2009; Ho et al., 2010; Madlener et al., 2007; Nandakumar et al., 2008). Anti-proliferative activity has also been reported for simple coumarins like 7-hydroxycoumarin (LopezGonzalez et al., 2004; Elinos-Báez et al., 2005), esculetin (Chu et al., 2001; Lee et al., 2008), 4-hydroxycoumarin (Velasco-Velázquez et al., 2003 and 2008); isofraxidin (Borris et al., 1980; Yamazaki and Tokiwa, 2010) and 7,8-dihydroxy-4-methyl coumarin (Riveiro et al., 2008). These coumarins were observed to arrest the cell cycle, induce apoptosis and inhibit tumor cell migration and invasion. It is thus possible that the dihydroxycoumarin sulfate and trihydroxycoumarin will show anti-proliferative activity when evaluated alone. Less is known regarding the anti-proliferative activity of koaburaside, the three turgorins and the new phenolic acid glycoside sulfate. The anticancer activity of these compounds remains to be determined. Possible synergistic interactions between these compounds may also play a role. 
Combinations of resveratrol and quercetin were observed to increase anticancer activity in colon cancer cells (Del Follo-Martinez et al., 2013).

\section{Conclusion}

An activity-guided isolation approach was used to determine the bioactive compounds in a commercial PST. This approach resulted in the isolation of seven (F6 - F12) of twenty-eight fractions with significant antioxidant and anti-proliferative activity. Fractions F7, F9 and F12, in particular, were the most promising as they inhibited the cell growth of all four cancer cell lines used in the study. LC-MS/MS analysis of these fractions revealed the presence of polyphenolic compounds GA, proanthocyanidins, dihydroxycoumarin sulfates, trihydroxycoumarin, turgorins and koaburaside. A new phenolic acid glycoside sulfate not previously shown in Pelargonium sidoides extracts was also tentatively identified. The compounds identified now need to be isolated and evaluated individually for antioxidant and anti-proliferative activity to ascertain that they contribute to the bioactivity of the Pelargonium sidoides. Synergistic and/or antagonistic interactions amongst these compounds as well as their mechanisms of action should also be further evaluated.

\section{Acknowledgements}

We would like to acknowledge the National Research Foundation of South Africa for funding this project. The funder had no role in study design; or in the collection, analysis and interpretation of data; or in the writing of the report; or in the decision to submit the article for publication. We also thank June Serem for assistance with ORAC and DCFH-DA antioxidant assays and Dr. Marietjie Stander for assistance with LC-MS/MS analysis.

\section{Conflict of interest}

All the authors declare no conflict of interest.

\section{References}

Afri M, Frimer AA, Cohen Y (2004) Active oxygen chemistry within the liposomal bilayer. Part IV: Locating 2',7'-dichlorofluorescein (DCF), 2',7'-dichlorodihydrofluorescein (DCFH) and 2',7'dichlorodihydrofluorescein diacetate (DCFH-DA) in the lipid bilayer. Chem Phys Lipids 131:123-133 
Bagchi D, Bagchi M, Stohs SJ, Das DK, Ray SD, Kuszynski CA, Joshi SS, Pruess HG (2000) Free radicals and grape seed proanthocyanidin extract: importance in human health and disease prevention. Toxicology 148:187-197

Bailly F, Maurin C, Teissier E, Vezin H, Cotelle P (2004) Antioxidant properties of 3hydroxycoumarin derivatives. Bioorg Med Chem 12:5611-5618

Biglari F, AlKarkhi AF, Easa AM (2008) Antioxidant activity and phenolic content of various date palm (Phoenix dactylifera) fruits from Iran. Food Chem 107:1636-1641

Boyd MR, Paull KD (1995) Some practical considerations and applications of the National Cancer Institute in vitro anticancer drug discovery screen. Drug Dev Res 34:91-109

Callemien D, Collin S (2008) Use of RP-HPLC-ESI (-)-MS/MS to differentiate various proanthocyanidin isomers in lager beer extracts. J Am Soc Brew Chem 66:109-115

Chou $\mathrm{T}$ (1991) The median-effect principle and the combination index for quantitation of synergism and antagonism. In: Rideout DC (ed) Synergism and antagonism in chemotherapy. Academic Press, San Diego, pp 61-102

Chuchalin AG, Berman B, Lehmacher W (2005) Treatment of acute bronchitis in adults with a pelargonium sidoides preparation (EPs 7630): a randomized, double-blind, placebo-controlled trial. Explore 1:437-445

Chung M, Lai M, Yen M, Wu R, Lin C (1997) Phenolics from Hypericum geminiflorum. Phytochemistry 44:943-947

Conrad A, Hansmann C, Engels I, Daschner FD, Frank U (2007) Extract of Pelargonium sidoides (EPs 7630) improves phagocytosis, oxidative burst, and intracellular killing of human peripheral blood phagocytes in vitro. Phytomedicine 14:46-51

Cos P, Rajan P, Vedernikova I, Calomme M, Pieters L, Vlietinck AJ, Augustyns K, Haemers, A, Vanden Berghe D (2002) In vitro antioxidant profile of phenolic acid derivatives. Free Radical Res $36: 711-716$

Del Follo-Martinez A, Banerjee N, Li X, Safe S, Mertens-Talcott S (2013) Resveratrol and quercetin in combination have anticancer activity in colon cancer cells and repress oncogenic microRNA-27a. Nutr Cancer 65:494-504 
Elinos-Baez C, Leon F, Santos E (2005) Effects of coumarin and 7OH-coumarin on bcl-2 and Bax expression in two human lung cancer cell lines in vitro. Cell Biol Int 29:703-708

Foti MC, Daquino C, Geraci C (2004) Electron-transfer reaction of cinnamic acids and their methyl esters with the DPPH* radical in alcoholic solutions. J Org Chem 69:2309-2314

Gödecke T, Kaloga M, Kolodziej H (2005) A phenol glucoside, uncommon coumarins and flavonoids from Pelargonium sidoides DC. Z Naturforsch B 60:677-682

He Y, Zhang L, Zhao M, Tsai S, Zong Y, Che C (2011) Phenolic compounds from Eurycorymbus cavaleriei. J Asian Nat Prod Res 13:575-580

Heijnen CG, Haenen GR, Vekemans JA, Bast A (2001) Peroxynitrite scavenging of flavonoids: structure activity relationship. Environ Toxicol Pharmacol 10:199-206

Heim KE, Tagliaferro AR, Bobilya DJ (2002) Flavonoid antioxidants: chemistry, metabolism and structure-activity relationships. J Nutr Biochem 13:572-584

Ho H, Chang C, Ho W, Liao S, Wu C, Wang C (2010) Anti-metastasis effects of gallic acid on gastric cancer cells involves inhibition of NF-אB activity and downregulation of PI3K/AKT/small GTPase signals. Food Chem Toxicol 48:2508-2516

Huang D, Ou B, Prior RL (2005) The chemistry behind antioxidant capacity assays. J Agric Food Chem 53:1841-1856

Itharat A, Houghton PJ, Eno-Amooquaye E, Burke PJ, Sampson JH, Raman A (2004) In vitro cytotoxic activity of Thai medicinal plants used traditionally to treat cancer. J Ethnopharmacol 90:3338

Ji BC, Hsu WH, Yang JS, Hsia TC, Lu CC, Chiang JH, Yang JL, Lin CH, Lin JJ, Suen LJ, Gibson Wood W, Chung JG (2009) Gallic acid induces apoptosis via caspase-3 and mitochondrion-dependent pathways in vitro and suppresses lung xenograft tumor growth in vivo. J Agric Food Chem 57:75967604

Kayser O, Kolodziej H (1995) Highly oxygenated coumarins from Pelargonium sidoides. Phytochemistry 39:1181-1185

Kayser O, Kolodziej H, Kiderlen AF (2001) Immunomodulatory principles of Pelargonium sidoides. Phytother Res 15:122-126 
Kayser O, Kolodziej H (1997) Antibacterial activity of extracts and constituents of Pelargonium sidoides and Pelargonium reniforme. Planta Med 63:508-510

Kim CE, Griffiths WJ, Taylor PW (2009) Components derived from Pelargonium stimulate macrophage killing of Mycobacterium species. J Appl Microbiol 106:1184-1193

Koch E, Hauer H, Stumpf K (2006) Use of Pelargonium sidoides and Pelargonium reniforme root extracts. US Patent 2006-0263448, filed June 24, 2005, issued Nov 23, 2006.

Kolodziej H (2007) Fascinating metabolic pools of Pelargonium sidoides and Pelargonium reniforme, traditional and phytomedicinal sources of the herbal medicine Umckaloabo. Phytomedicine 14:9-17

Kolodziej H, Kiderlen AF (2007) In vitro evaluation of antibacterial and immunomodulatory activities of Pelargonium reniforme, Pelargonium sidoides and the related herbal drug preparation EPs 7630 . Phytomedicine 14:18-26

Kolodziej H, Kayser O, Radtke OA, Kiderlen AF, Koch E (2003) Pharmacological profile of extracts of Pelargonium sidoides and their constituents. Phytomedicine 10:18-24

Kumaran A, Karunakaran RJ (2007) In vitro antioxidant activities of methanol extracts of five Phyllanthus species from India. LWT-Food Sci Technol 40:344-352

Lee SH, Park C, Jin C, Kim G, Moon S, Hyun JW, Lee WH, Choi BT, Kwon TK, Yoo YH (2008) Involvement of extracellular signal-related kinase signaling in esculetin induced G1 arrest of human leukemia U937 cells. Biomed Pharmacother 62:723-729

Lewu FB, Grierson DS, Afolayan AJ (2006) The leaves of Pelargonium sidoides may substitute for its roots in the treatment of bacterial infections. Biol Conserv 128:582-584

Li H, Wang X, Li Y, Li P, Wang H (2009) Polyphenolic compounds and antioxidant properties of selected China wines. Food Chem 112:454-460

Lizogub VG, Riley DS, Heger M (2007) Efficacy of a pelargonium sidoides preparation in patients with the common cold: a randomized, double blind, placebo-controlled clinical trial. Explore 3:573584

Ma G, Chong L, Li X, Khan IA, Walker LA, Khan SI (2010) Selective inhibition of human leukemia cell growth and induction of cell cycle arrest and apoptosis by pseudolaric acid B. J Cancer Res Clin 136:1333-1340 
Madlener S, Illmer C, Horvath Z, Saiko P, Losert A, Herbacek I, Grusch M, Elford HL, Krupitza G, Bernhaus A, Fritzer-Szekeres M, Szekeres T (2007) Gallic acid inhibits ribonucleotide reductase and cyclooxygenases in human HL-60 promyelocytic leukemia cells. Cancer Lett 245:156-162

Mativandlela SPN, Lall N, Meyer JJM (2006) Antibacterial, antifungal and antitubercular activity of (the roots of) Pelargonium reniforme (CURT) and Pelargonium sidoides (DC) (Geraniaceae) root extracts. S Afr J Bot 72:232-237

Matthys H, Kamin W, Funk P, Heger M (2007) Pelargonium sidoides preparation (EPs 7630) in the treatment of acute bronchitis in adults and children. Phytomedicine 14:69-73

Matthys H, Eisebitt R, Seith B, Heger M (2003) Efficacy and safety of an extract of Pelargonium sidoides (EPs 7630) in adults with acute bronchitis. A randomised, double-blind, placebo-controlled trial. Phytomedicine 10:7-17

Meir S, Kanner J, Akiri B, Philosoph-Hadas S (1995) Determination and involvement of aqueous reducing compounds in oxidative defense systems of various senescing leaves. J Agr Food Chem 43:1813-1819

Michaelis M, Doerr HW, Cinatl J Jr (2011) Investigation of the influence of EPs(R) 7630, a herbal drug preparation from Pelargonium sidoides, on replication of a broad panel of respiratory viruses. Phytomedicine 18:384-386

Nandakumar V, Singh T, Katiyar SK (2008) Multi-targeted prevention and therapy of cancer by proanthocyanidins. Cancer Lett 269:378-387

Noldner M, Schotz K (2007) Inhibition of lipopolysaccharide-induced sickness behavior by a dry extract from the roots of Pelargonium sidoides (EPs 7630) in mice. Phytomedicine 14: 27-31

Ou B, Hampsch-Woodill M, Prior RL (2001) Development and validation of an improved oxygen radical absorbance capacity assay using fluorescein as the fluorescent probe. J Agr Food Chem 49:4619-4626

Pérez-Magariño S, Revilla I, Gonzalez-SanJose ML, Beltran S (1999) Various applications of liquid chromatography-mass spectrometry to the analysis of phenolic compounds. Journal of Chromatogr A $847: 75-81$ 
Rawat S, Bhatt ID, Rawal RS (2011) Total phenolic compounds and antioxidant potential of Hedychium spicatum Buch. Ham. ex D. Don in west Himalaya, India. J Food Compos Anal 24:574579

Rice-Evans CA, Miller NJ, Paganga G (1996) Structure-antioxidant activity relationships of flavonoids and phenolic acids. Free Radical Bio Med 20:933-956

Riveiro ME, Vazquez R, Moglioni A, Gomez N, Baldi A, Davio C, Shayo C (2008) Biochemical mechanisms underlying the pro-apoptotic activity of 7, 8-dihydroxy-4-methylcoumarin in human leukemic cells. Biochem Pharmacol 75:725-736

Royer M, Diouf PN, Stevanovic T (2011) Polyphenol contents and radical scavenging capacities of red maple (Acer rubrum L.) extracts. Food Chem Toxicol 49:2180-2188

Schildknecht H (1984) Turgorins-new chemical messengers for plant behaviour. Endeavour 8:113117

Schnitzler P, Schneider S, Stintzing FC, Carle R, Reichling J (2008) Efficacy of an aqueous Pelargonium sidoides extract against herpesvirus. Phytomedicine 15:1108-1116

Serem JC, Bester MJ (2012) Physicochemical properties, antioxidant activity and cellular protective effects of honeys from southern Africa. Food Chem 133:1544-1550

Southorn PA, Powis G (1996) Free radicals in cell biology. In: Bittar EE, Bittar N (eds) Principles of Medical Biology Volume 4 Part 2. JAI Press, Greenwich, pp 349-377

Spranger I, Sun B, Mateus AM, Freitas VD, Ricardo-da-Silva JM (2008) Chemical characterization and antioxidant activities of oligomeric and polymeric procyanidin fractions from grape seeds. Food Chem 108:519-532

Sroka Z, Cisowski W (2003) Hydrogen peroxide scavenging, antioxidant and anti-radical activity of some phenolic acids. Food Chem Toxicol 41:753-758

Steenkamp V, Gouws M (2006) Cytotoxicity of six South African medicinal plant extracts used in the treatment of cancer. S Afr J Bot 72:630-633

Sultana B, Anwar F, Przybylski R (2007) Antioxidant activity of phenolic components present in barks of Azadirachta indica, Terminalia arjuna, Acacia nilotica, and Eugenia jambolana Lam. trees. Food Chem 104:1106-1114 
Takimoto CH (2003) Anticancer drug development at the US National Cancer Institute. Cancer Chemoth Pharm 52:S29-33

Teow CC, Truong V, McFeeters RF, Thompson RL, Pecota KV, Yencho GC (2007) Antioxidant activities, phenolic and $\beta$-carotene contents of sweet potato genotypes with varying flesh colours. Food Chem 103:829-838

Velasco-Velázquez MA, Salinas-Jazmín N, Mendoza-Patiño N, Mandoki JJ (2008) Reduced paxillin expression contributes to the antimetastatic effect of 4-hydroxycoumarin on B16-F10 melanoma cells. Cancer Cell Int 8:2807-2868

Vukovic N, Sukdolak S, Solujic S, Niciforovic N (2010) An efficient synthesis and antioxidant properties of novel imino and amino derivatives of 4-hydroxy coumarins. Arch Pharm Res 33:5-15

Yamazaki T, Tokiwa T (2010) Isofraxidin, a coumarin component from Acanthopanax senticosus, inhibits matrix metalloproteinase-7 expression and cell invasion of human hepatoma cells. Biol Pharm Bull 33:1716-1722

Zhou K, Yin J, Yu LL (2006) ESR determination of the reactions between selected phenolic acids and free radicals or transition metals. Food Chem 95:446-457 